\title{
VELOCITY SECTIONS IN RAFT RIVER, IDAHO GEOTHERMAL AREA FROM SEISMIC REFRACTION
}

by

HANS D. ACKERMANN

\author{
Prepared in cooperation with \\ Energy Research Development Administration \\ (formerly the U.S. Atomic Energy Commission)
}

This report has not been edited

USGS Open File

or reviewed for conformity to

Geological Survey standards.

Report $\underline{75-106}$ 
Velocity sections in Raft River, Idaho gcothermal area from seismic refraction

by

Hans D. Ackermann, U.S. Geological Survey

Twenty-five seismic refraction spreads were recorded in the summer and fall of 1974 as part of the U.S. Geological Survey's geothermal exploration program in the Raft River, Idaho area in cooperation with the Energy Research Development Administration (formerly the U.S. Atomic Energy Commission). This report shows the location of these seismic spreads and the interpreted velocity sections.

The scale for the location map (fig. 1) is $1: 48,000$, which is the same as that generally used for the various reports of this project. The velocity sections (fig. 2) are cross-sections showing layer velocities in kilometres per second. All of the velocity sections show depths to at least a $3.0 \mathrm{~km} / \mathrm{sec}(\sim 9,800 \mathrm{ft} / \mathrm{sec})$ layer. The seismic data, however, indicate that the entire area is underlain by a $5.2-7.0 \mathrm{~km} / \mathrm{sec}$ $(17,000-23,000 \mathrm{ft} / \mathrm{sec})$ horizon which is defined as basement. The basement horizon could be interpreted for only some of the velocity sections. Basement is shown where it could be interpreted. 